\title{
REPRODUCTIVE ISOLATION AND INTROGRESSION BETWEEN NOTROPIS CORNUTUS AND NOTROPIS CHRYSOCEPHALUS (FAMILY CYPRINIDAE): COMPARISON OF MORPHOLOGY, ALLOZYMES, AND MITOCHONDRIAL DNA
}

\author{
Thomas E. Dowling,' Gerald R. Smith, ANd Wesley M. Brown \\ Laboratory of Molecular Systematics, Museum of Zoology and Department of Biology, \\ The University of Michigan, Ann Arbor, MI 48109
}

\begin{abstract}
Hybrid zones in fluvial fishes may be heterogeneous from drainage to drainage. The comparison of data from morphology, allozymes, and mitochondrial DNA (mtDNA) indicates variability in the causes and degree of restriction of gene flow between Notropis cornutus and Notropis chrysocephalus. Allozyme marker loci show frequency-dependent introgression; i.e., the rarer species, whichever it is at a particular locality, tends to exhibit a higher proportion of introgressed alleles. Unlike allozymes, introgression of mtDNA haplotypes varies geographically. In westward-flowing Michigan drainages, $N$. cornutus mtDNA haplotypes are more common in $F_{1}$ hybrids and backcrosses, independent of parental frequencies. In eastward-flowing Michigan drainages, $N$. chrysocephalus mtDNA is more common in $F_{1}$ hybrids and backcrosses; this pattern may be due to local ecological effects or frequency-dependent introgression. Morphological data alone are not sufficient to distinguish all classes of hybrids. The lack of concordance of morphological, allozymic, and mtDNA introgression patterns implies operation of one or two factors: 1) geographically variable patterns of selection against different hybrid and backcross combinations or 2) genetic differences between Michigan populations inhabiting eastward-and westward-flowing drainage systems accumulated during historical isolation.
\end{abstract}

\section{Received July 20, 1987. Accepted November 10, 1988}

The discovery of numerous stable hybrid zones (reviewed by Barton and Hewitt [1981, 1985] and Moore [1977]) and the paucity of evidence supporting reinforcement of reproductive isolation (e.g., Muller, 1942; Kaneshiro, 1976, 1980; Paterson, 1978; Moore, 1979, 1987; Heth and Nevo, 1981; Barton and Hewitt, 1985; Bush and Howard, 1985; Dowling and Moore, 1985a; Moore and Buchanan, 1985) has led to a renewed interest in the study of gene flow and isolating mechanisms. In this context, the study of speciation involves analysis of the causes of restriction of gene flow between incipient species. Such analysis is especially informative in situations where hybridization occurs and reproductive isolation is incomplete.

The incompletely isolated species (or semispecies) of North American minnows, Notropis cornutus and Notropis chrysocephalus, are ideal subjects for the study of reproductive isolation. Early morphological analyses (Gilbert, 1961, 1964; Smith et al., 1981) of populations from the region of overlap (northern Illinois, Indiana, and

\footnotetext{
1 Present address: Department of Zoology, Arizona State University, Tempe, AZ 85287.
}

Ohio, southern Michigan and Ontario, and western Pennsylvania and New York) between these species provided evidence for incomplete reproductive isolation at some, but not all, localities. Morphometric and electrophoretic study of sympatric populations revealed extensive hybridization and introgression; however, significant deficiencies of heterozygotes for electrophoretic marker loci, relative to Hardy-Weinberg expectations, indicated that the two species are reproductively isolated to some extent (Dowling and Moore, 1984). By following the relative hybridity of specific age-classes through time, Dowling and Moore (1985a) demonstrated that reproductive isolation was at least partly attributable to selection against adult hybrids.

Restriction-endonuclease analysis of mitochondrial DNA (mtDNA) is now widely used for evolutionary studies (reviewed by Wilson et al. [1985], Avise [1986], Avise et al. [1987], and Moritz et al. [1987]). The rapid rate of vertebrate mtDNA evolution (Brown et al., 1979; Brown et al., 1982; Vawter and Brown, 1986) and the strictly maternal mode of inheritance (reviewed by Avise and Lansman [1983]) make this molecule a useful genetic marker for the 
study of gene exchange between closely related species. Studies of mtDNA in hybrid zones have demonstrated variation that is either concordant (Avise et al., 1984; Szymura et al., 1985; Wilson et al., 1985) or discordant (Powell, 1983; Ferris et al., 1983; Spolsky and Uzzell, 1984; Harrison et al., 1987; Tegelstrom, 1987) with previously described morphological and allozymic patterns.

Since mtDNA is maternally inherited, it can be used to identify the maternal component involved in hybridization events and, in conjunction with other characters, to improve inferences about reproductive isolation. In this paper, we employ mtDNA, in conjunction with allozymes, as a genetic marker for identifying the maternal component involved in the production of $F_{1}$ and backcross hybrids in sympatric populations of Notropis cornutus and Notropis chrysocephalus. The strict maternal inheritance of mtDNA produces specific expectations regarding the frequency of each species' haplotypes in each hybrid class. If mating between $N$. cornutus and $N$. chrysocephalus were random (i.e., reciprocal), if sex ratios were equivalent, and if the $F_{1}$ progeny of the reciprocal crosses were equally fit, the mtDNA of both species would be equally represented in a sample of $F_{1}$ hybrids. Furthermore, if matings among the parental species, $F_{1}$ hybrids, and backcrosses were completely at random and the progeny of all mating combinations were equally fit, the frequency of mtDNA haplotypes in backcross hybrids would be proportional to the frequencies of the parental alleles in the population. Thus, deviations from expected proportions of mtDNA haplotypes in $F_{1}$ and backcross hybrids would be indicative of assortative mating, selection against specific hybrid combinations, or both.

Analyses of morphology, mtDNA, and allozymes are also used to estimate the relative directionality of introgression in hybrid populations. Directionality can be inferred from comparisons of the extent of introgression between species for allozymic and mtDNA markers. Differences between the extent of mtDNA and allozymic introgression are expected because of the uniparental inheritance of mtDNA (Takahata and Slatkin, 1984; Barton and Jones, 1983;
Avise and Saunders, 1984). Interlocality differences in the ratio of mtDNA to allozymic introgression may be indicative of differences in reproductive isolation from locality to locality.

\section{MATERIALS AND METHODS}

Notropis cornutus, Notropis chrysocephalus, and their hybrids were collected by seining at localities from southeastern and south-central Michigan (Fig. 1). The Huron and Raisin rivers (localities 1-4 in Fig. 1) flow eastward into Lake Erie; the Grand and Kalamazoo rivers (localities 5-7) drain westward into Lake Michigan. Multiple collections were made at several of these localities $(2,3,5$, and 6$)$. Because allozyme frequencies were not significantly different within localities (with the exception of locality 5 , where subsamples were small), subsamples were pooled for analysis.

Morphological Analysis. - Each specimen was scored for the following meristic and pigment characters (which are independent of size): number of lateral-line scales, number of circumferential scales, number of anterior dorsolateral scales, and the presence or absence of chin and back pigmentation. The first principal component (PC1) was used as a classification function to identify $N$. cornutus, $N$. chrysocephalus, and their hybrids (as described in Dowling and Moore [1984]). Morphological measures from "pure" representatives of $N$. cornutus and $N$. chrysocephalus (individuals collected well outside the area of hybridization) were used to determine four sets of principal-component character loadings for calculation of classification scores (for character loadings and distribution of classification scores, see table 1 and figure 2 in Dowling and Moore [1984]). Four sets of character loadings were generated, because some meristic characters were lost during handling of some specimens, particularly smaller individuals. Classification scores were calculated for all individuals using these character loadings. Individuals were identified as "morphological" $N$. cornutus or $N$. chrysocephalus if their principal-component scores fell within the range obtained from analysis of reference specimens or as hybrids (including backcrosses) if the PCl scores fell between the ranges of reference $N$. cornutus and $N$. 


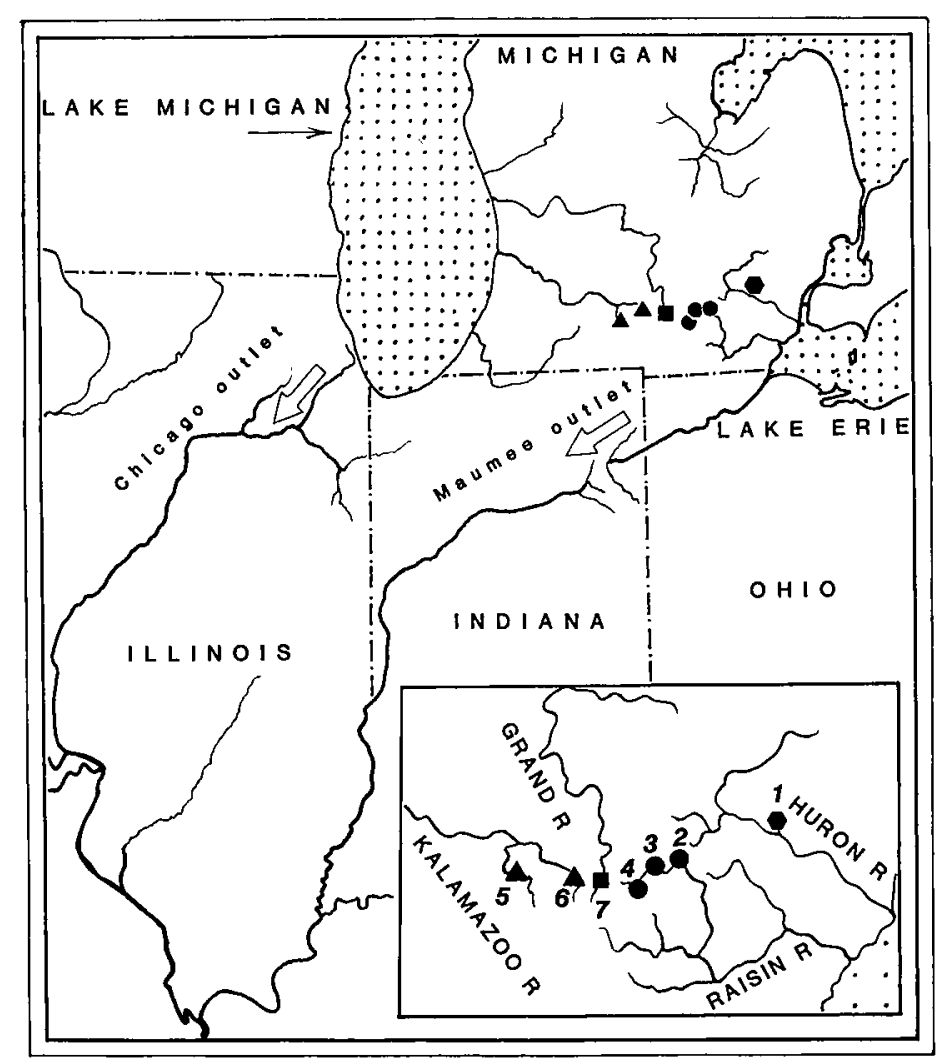

FIG. 1. Map of drainages and the southeastern Michigan localities discussed in this analysis of hybridization between $N$. cornutus and $N$. chrysocephalus. Numbered localities and collection dates are as follows: 1) Loch Alpine Creek (tributary of the Huron River), North Huron River Dr., ca. 5 mi northwest of Ann Arbor, Washtenaw Co. (31 March 1986); 2) Raisin River, Sharon Hollow, Washtenaw Co. (2 May, 1 July, and 14 July 1986); 3) Raisin River, Norvell, Jackson Co. (27 October 1985, 28 July, and 20 August 1986); 4) Goose Creek (tributary of the Raisin River), city park in Brooklyn, Jackson Co. (2 May 1986); 5) South Branch of the Kalamazoo River, 281/2 Mile Rd., ca. $6.5 \mathrm{mi}$ south of Albion, Calhoun Co. (1 April, 27 April, and 6 August 1986); 6) North Branch of the Kalamazoo River, Horton, Jackson Co. (1 April, 27 April, and 6 August 1986); 7) Grand River, Culver Rd., ca. $7.5 \mathrm{mi}$ west of Brooklyn, Jackson Co. (20 August 1986). Arrows identify the direction of glacial lake outlets; see Discussion.

chrysocephalus. This method does not correctly classify $100 \%$ of the individuals, however, because some hybrid individuals fall in the parental clusters (Neff and Smith, 1978).

Protein Electrophoresis. - The allozyme phenotypes for the Pep-B and Pep-S (peptidases; E.C. 2.4.13.11) and Pgm-A (phosphoglucomutase; E.C. 2.7.5.1) loci were resolved as described in Dowling and Moore $(1984,1985 b)$, except that samples were homogenized in deionized distilled water and centrifuged at $13,605 \mathrm{~g}$ and $4^{\circ} \mathrm{C}$ for $10 \mathrm{~min}$ utes in order to remove large cellular debris. $\mathrm{Pep}-\mathrm{S}$ and $\mathrm{Pgm}-\mathrm{A}$ are fixed mobility differences that completely differentiate $N$. cor- nutus and $N$. chrysocephalus. There is an allelic frequency difference between these species at $P e p-B ; N$. chrysocephalus is monomorphic for a fast allele, while $N$. cornutus exhibits this fast electromorph and, more commonly, a unique slow allele (frequency ranging from 0.65 to 0.86 in northern Michigan populations).

Isolation and Restriction-Endonuclease Analysis of $m t D N A$. - Mitochondrial DNA was isolated from heart, liver, kidney, gonad, and, occasionally, from muscle and brain, as described by Densmore et al. (1985) and Wright et al. (1983), with the following modifications. 1) Tissues were homogenized in a modified grinding buffer $(10 \mathrm{mM}$ 
Tris, $100 \mathrm{mM}$ EDTA, $10 \mathrm{mM} \mathrm{NaCl}, 0.25$ $\mathrm{M}$ sucrose, $\mathrm{pH}$ 7.5) with two 15-20-second bursts using a Tekmar Tissumizer ${ }^{\circledR}$. 2) After the high-speed spin $(14,000 \mathrm{rpm}$, Sorvall SS-34 rotor), the enriched mitochondrial pellet was resuspended in $1.0 \mathrm{ml}$ of TE $(10$ mM Tris, 100 mM EDTA, pH 7.5), 0.125 $\mathrm{ml}$ of $20 \%$ sodium dodecyl sulfate (SDS) was added, and SDS and nuclear DNA were precipitated by the addition of $0.188 \mathrm{ml}$ of saturated cesium chloride ( $\mathrm{CsCl}$ in water). 3) Following centrifugation at $12,000 \mathrm{rpm}$ (Sorvall SS-34 rotor) to remove the precipitate ( $\mathrm{CsCl}$, SDS, and nuclear DNA), the supernatant density was adjusted to 1.40 $\mathrm{g} / \mathrm{ml}$ by the addition of solid $\mathrm{CsCl}$. At this point, the sample could be stored indefinitely at $-20^{\circ} \mathrm{C}$, or the procedure could be continued by adding propidium iodide (PI) stock solution $(2 \mathrm{mg} / \mathrm{ml}$ in $10 \mathrm{mM}$ Tris, 1 mM EDTA, pH 7.5) to a final PI concentration of $300-350 \mu \mathrm{g} / \mathrm{ml}$. The volume of each sample was measured, and the samples were transferred to Seton polyallomer ultracentrifuge tubes and then underlayered with $1.70 \mathrm{~g} / \mathrm{ml} \mathrm{CsCl}$, PI solution (PI at 100 micrograms $/ \mathrm{ml} ; 1.3 \mathrm{ml}$ of $1.70 \mathrm{~g} / \mathrm{ml}$ solution was used for each $1 \mathrm{ml}$ of sample at $1.40 \mathrm{~g} / \mathrm{ml}$ ). The resulting step gradient was overlaid with light mineral oil to fill the tube and centrifuged for 20-24 hours at 36,000 $\mathrm{rpm}$ and $21^{\circ} \mathrm{C}$ in a Beckman SW60 rotor. The mtDNA was collected by bottom puncture (as described in Wright et al. [1983]). $\mathrm{PI}$ and $\mathrm{CsCl}$ were removed by extraction with isopropyl alcohol (saturated with $\mathrm{CsCl}$ saturated water) and dialysis (at $4^{\circ} \mathrm{C}$ ), first against Dowex AG50-X8 in $1 \mathrm{M} \mathrm{NaCl}, 10$ $\mathrm{mM}$ Tris, and $1 \mathrm{mM}$ EDTA at $\mathrm{pH} 7.5$ for 12-18 hours and then against $1 \mathrm{mM}$ Tris and $0.1 \mathrm{mM}$ EDTA at $\mathrm{pH} 7.5$ for 18-24 hours.

Nearly all mtDNAs were characterized as $N$. cornutus or $N$. chrysocephalus by digestion with the following restriction endonucleases, using the conditions recommended by the suppliers (New England Biolabs, Boehringer Mannheim, and International Biotechnologies, Inc.): Ava I, Hind III, and $M b o$ I. Fragments produced by enzymatic digestion were end-labelled as described in Wright et al. (1983), separated by electrophoresis through $1.2 \%$ agarose and $4.0 \%$ polyacrylamide slab gels, and visualized by autoradiography as described by Brown (1980). The mtDNAs of $N$. cornutus and $N$. chrysocephalus differ by a minimum of two and eight restriction-site changes for Hind III and $A v a$ I, respectively, and by an undetermined large number of site changes for Mbo I (Fig. 2).

Identification of $F_{I}$ and Backcross Hybrids. - Each individual was identified as $N$. cornutus, $N$. chrysocephalus, $\mathrm{F}_{1}$, or backcross, using morphology, allozymes, and mtDNA restriction-fragment patterns $(\mathrm{Ta}-$ ble 1, Fig. 3). Individuals were considered to be $N$. cornutus or $N$. chrysocephalus if their principal-component classification scores fell within the range calculated from reference specimens known to be remote from hybrid influence and if they exhibited the corresponding mtDNA and electrophoretic patterns. Two of the marker loci (Pgm-A and Pep-S) are diagnostic for $N$. cornutus and $N$. chrysocephalus. Pep-B is not completely diagnostic for either species; however, "pure" N. chrysocephalus must be monomorphic for the fast allele.

$F_{1}$ hybrids were identified using electrophoretic characters alone. $F_{1}$ 's must be heterozygous for the $P e p-S$ and $P g m-A$ loci and either heterozygous at the Pep-B locus or homozygous for the shared (N. chrysocephalus) allele. Because mtDNA is uniparentally inherited, it cannot be used alone to identify $F_{1}$ hybrids, and use of morphology alone is also unreliable because $F_{1}$ 's may fall into parental clusters (Neff and Smith, 1978; Ross and Cavender, 1981; Lamb and Avise, 1987).

Individuals with discordant protein, morphological, or mtDNA traits were considered to be backcross hybrids. These are typified by interjacency of morphological characters (as reflected by PCl scores) between or among those of the "pure" parentals, heterozygosity at either of the two allozyme markers (any of the three for backcrosses to $N$. chrysocephalus) or alternate alleles at these two loci, and/or discordance of mtDNA haplotype with the other character states. Because of the rarity of $F_{1}$ 's in natural populations, most backcross hybrids are not the result of matings between $F_{1}$ 's and an individual of either parental species but appear to be the results of several generations of backcrossing. 


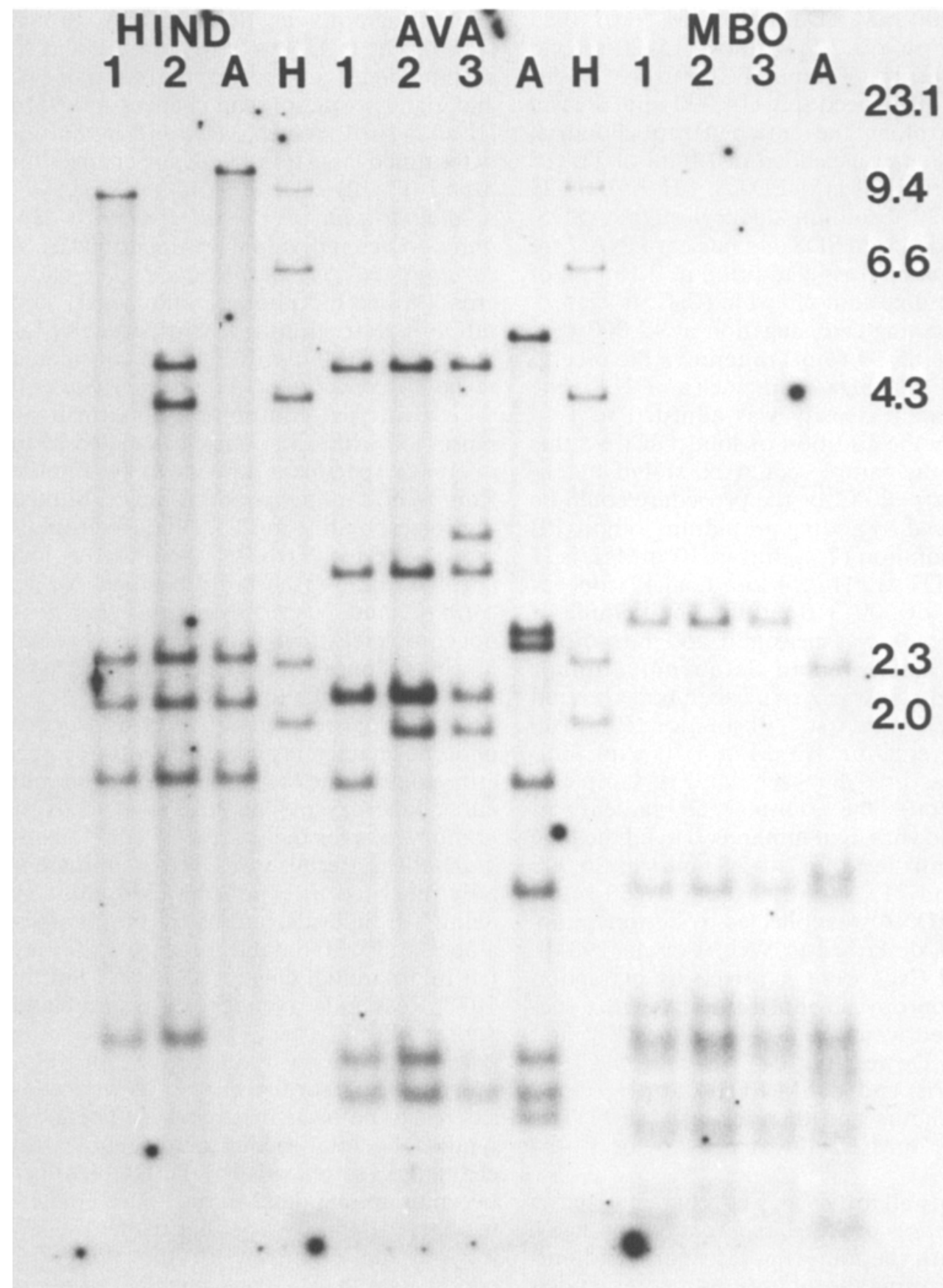

FIG. 2. Autoradiograph of a $1.2 \%$ agarose gel of $N$. cornutus and $N$. chrysocephalus mtDNA digested with Hind III, Ava I, and Mbo I. Numbers (1-3) depict some of the different $N$. cornutus haplotypes, A represents the major $N$. chrysocephalus haplotypes, and $H$ represents the size standard (Hind III-digested lambda DNA), with fragment sizes (in kilobase pairs) on the right. 
TABLE 1. Multicharacter identifications of all individuals in this study. $N$. cornutus and $N$. chrysocephalus are abbreviated as $\mathrm{CO}$ and $\mathrm{CH}$, respectively. Sample sizes are presented in the column labeled $N$, and backcrosses are presented in the columns $\mathrm{B}_{\mathrm{CO}}$ and $\mathrm{B}_{\mathrm{CH}}$; the number of backcrosses with only nonconcordant mtDNA haplotypes are shown in parentheses. Locality numbers refer to those in Figure 1.

\begin{tabular}{crrrrrr}
\hline \hline Locality & $N$ & $\mathrm{CO}$ & $\mathrm{B}_{\mathrm{CO}}$ & $\mathrm{F}_{1}$ & $\mathrm{~B}_{\mathrm{CH}}$ & $\mathrm{CH}$ \\
\hline Eastern drainages: & & & & & & \\
1 & 50 & 0 & $1(1)$ & 2 & $19(1)$ & 28 \\
2 & 60 & 4 & $10(1)$ & 5 & $17(3)$ & 24 \\
3 & 108 & 6 & $3(1)$ & 8 & $23(3)$ & 68 \\
4 & 51 & 29 & $11(6)$ & 3 & $4(1)$ & 4 \\
Western drainages: & & & & & & \\
5 & 53 & 26 & $13(8)$ & 1 & $11(6)$ & 2 \\
6 & 77 & 3 & $6(1)$ & 9 & $38(34)$ & 21 \\
7 & 33 & 1 & $0(0)$ & 2 & $16(13)$ & 14 \\
\hline
\end{tabular}

The limited number of characters used for classification results in an underestimate of the frequency of backcross individuals, but the frequency of misidentification is difficult to estimate, because it is dependent on the relative proportions of $F_{1}$ and backcross hybrids, which varies markedly between populations. Undoubtedly, some individuals classified as $\mathrm{F}_{1}, N$. cornutus, or $N$. chrysocephalus are actually backcross hybrids, with the $F_{1}$ 's being identified most accurately.

\section{RESULTS}

Statistical analysis of morphological and electrophoretic data from these seven populations (Table 2) provided results similar to those described previously (Dowling and Moore, 1984). Morphological characters demonstrated large modal differences between $N$. cornutus and $N$. chrysocephalus. There were few hybrids at localities 4 and 5 (as in figure 2C of Dowling and Moore [1984]), but hybrids were relatively common at localities $1,2,3,6$, and 7 , with frequencies about equal to the rarer species (as in figure 2D of Dowling and Moore [1984]). Allele frequencies for the three marker loci (Pgm-A, Pep-S, and Pep-B) reflected proportions similar to the morphological analysis of $N$. cornutus, $N$. chrysocephalus, and their hybrids in these populations. Tests of Hardy-Weinberg equilibrium ( $F$ test of Cockerham [1969, 1973]) revealed significant deficiencies of heterozygotes at all three marker loci in six of the seven populations (localities 2-7). Failure to detect heterozygote deficiencies in the Huron River pop- ulation (locality 1 ) is consistent with the small expected values $(<1)$ of the rare $(N$. cornutus) homozygote.

Analysis of $F_{1}$ Hybrids. - The number of $F_{1}$ hybrids found at each locality and the distribution of mtDNA haplotypes are presented in Table 3 . This class of hybrids varies from rare to common, making up 1.9$11.7 \%$ of the specimens collected at each locality. Sample sizes from the Raisin River at Norvell (locality 3 ) and the Kalamazoo River at Horton (locality 6) were large enough for statistical analysis, but rarity of $F_{1}$ hybrids prohibited statistical tests of the distribution of mtDNA haplotypes from the remaining localities. If mating is random (i.e., reciprocal), sex ratios are equivalent, and progeny from each of the reciprocal crosses are equally fit, then each mtDNA haplotype should be equally represented in the $F_{1}$ hybrids.

Binomial tests (Zar, 1974 pp. 287-289) of $F_{1}$ hybrids from localities 3 and 6 revealed significant deviations from the expected distribution of mtDNA haplotypes (Table 3). From the Raisin River at Norvell (locality 3 ), all eight of the $F_{1}$ hybrids possessed $N$. chrysocephalus mtDNA, and eight of nine from the Kalamazoo River at Horton (locality 6) possessed $N$. cornutus mtDNA, suggesting that surviving $F_{1}$ hybrids are the result of different reciprocal crosses at these localities. Apparently, the surviving $F_{1}$ 's usually result from matings of male $N$. chrysocephalus with female $N$. cornutus from the Kalamazoo River at Horton, while they result from the reciprocal cross $(N$. cornutus males $\times N$. chrysocephalus females) in the Raisin River at Norvell. 


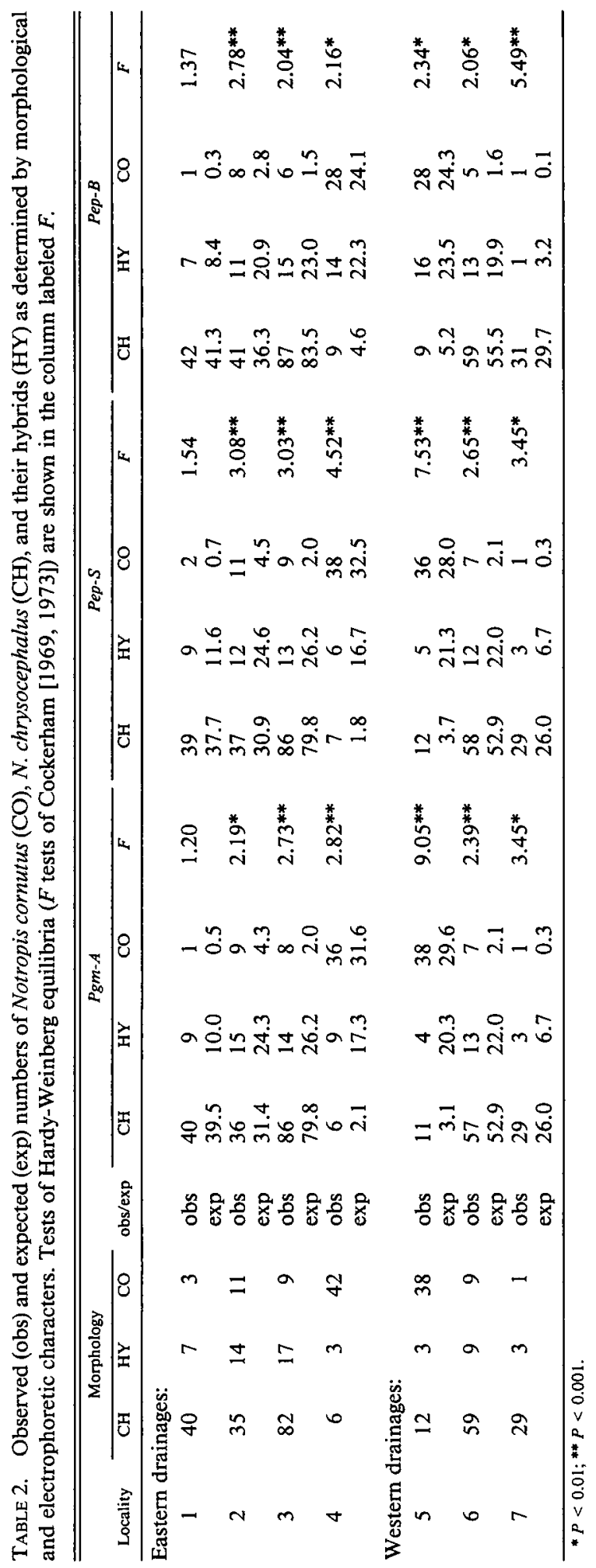


TABLE 3. Number of $N$. cornutus (CO) and N. chrysocephalus $(\mathrm{CH}) \mathrm{mtDNA}$ haplotypes found in $\mathrm{F}_{1}$ hybrids from seven populations. The column headed $\% \mathrm{~F}_{1}$ presents the percentage of $F_{1}$ hybrids in each population. Significance levels of binomial tests for populations from Norvell (site 3) and Horton (site 6) are presented in the column labeled $P$. Dashes indicate comparisons not attempted due to small sample sizes. See text for discussion of statistical analyses.

\begin{tabular}{|c|c|c|c|c|}
\hline Locality & $\% \mathrm{~F}_{1}$ & $\mathrm{CO}$ & $\mathrm{CH}$ & $P$ \\
\hline \multicolumn{5}{|c|}{ Eastern drainages: } \\
\hline $\begin{array}{l}1 \\
2 \\
3 \\
4\end{array}$ & $\begin{array}{l}4.0 \\
8.3 \\
7.4 \\
5.9\end{array}$ & $\begin{array}{l}0 \\
1 \\
0 \\
2\end{array}$ & $\begin{array}{l}2 \\
4 \\
8 \\
1\end{array}$ & $\begin{array}{c}- \\
- \\
0.004 \\
-\end{array}$ \\
\hline \multicolumn{5}{|c|}{ Western drainages: } \\
\hline $\begin{array}{l}5 \\
6 \\
7\end{array}$ & $\begin{array}{r}1.9 \\
11.7 \\
6.1\end{array}$ & $\begin{array}{l}1 \\
8 \\
1\end{array}$ & $\begin{array}{l}0 \\
1 \\
1\end{array}$ & $\begin{array}{c}-\overline{0} \\
-\end{array}$ \\
\hline
\end{tabular}

Analysis of Backcross Hybrids.-Backcross hybrids make up a large fraction of each population (24.1-57.1\%; Table 4). If hybridization were random and all progeny were equally fit, the distribution of mtDNA haplotypes in backcross hybrids would reflect the relative abundance of $N$. cornutus and $N$. chrysocephalus at each locality, and the frequency of $N$. cornutus and $N$. chrysocephalus mtDNA haplotypes found in the backcross hybrids would not differ significantly from the frequency of diagnostic alleles at the $P g m-A$ and Pep-S marker loci in the population. $G$ tests (Zar, $1974 \mathrm{pp}$. 53-54) of the observed and expected frequencies of mtDNA haplotypes reveal significant departures from the expected distributions at five localities $(1,3,4,6$, and 7 ), suggesting that backcrossing is usually not random or that progeny resulting from different backcrosses are not equally fit. As in the analysis of $F_{1}$ hybrids, backcrosses from the westward flowing (Lake Michigan) drainages usually exhibit $N$. cornutus mtDNA, while backcrosses from the eastward flowing (Lake Erie) drainages tend to have $N$. chrysocephalus mtDNA, although $N$. cornutus mtDNA is more common than expected based on the assumption of random mating (Table 4).

\section{Extent and Directionality of Introgression}

Patterns of backcross allele penetrance into parental types are distinctly different in
TABLE 4. Distribution of $N$. cornutus (CO) and $N$. chrysocephalus $(\mathrm{CH})$ mtDNA haplotypes in backcross hybrids. The percentage of backcross hybrids in these populations is presented in the column headed $\%$. The $G$ and significance $(P)$ values are from the $G$ tests of the observed (obs) and expected (exp) numbers of mtDNA haplotypes. Expected values were calculated from predictions based on the numbers of allozyme alleles $(P g m-A+P e p-S)$ at each locality. See text for further details on the statistical analyses.

\begin{tabular}{cccccccc}
\hline \hline \multicolumn{2}{c}{ Locality } & $\%$ & & CO & CH & $G$ & $P$ \\
\hline \multicolumn{2}{c}{ Eastern drainages: } & & & & \\
1 & 40.0 & obs & 6 & 14 & 4.59 & $<0.05$ \\
& & exp & 2.4 & 17.6 & & \\
2 & 45.0 & obs & 8 & 19 & 0.04 & ns \\
& & exp & 7.5 & 19.5 & & \\
3 & 24.1 & obs & 10 & 16 & 9.36 & $<0.005$ \\
& & exp & 3.7 & 22.3 & & \\
4 & 29.4 & obs & 6 & 9 & 11.43 & $<0.001$ \\
& & exp & 12.0 & 3.0 & & \\
Western drainages: & & & & \\
5 & 45.3 & obs & 15 & 9 & 1.52 & ns \\
& & exp & 17.8 & 6.2 & & \\
6 & 57.1 & obs & 41 & 3 & 123.22 & $<0.001$ \\
7 & & exp & 7.6 & 36.4 & & \\
7 & 48.5 & obs & 14 & 2 & 60.79 & $<0.001$ \\
& & $\exp$ & 1.2 & 14.8 & & \\
\hline
\end{tabular}

allozymic, morphological, and mtDNA data sets (Fig. 3). The direction and extent of introgression were estimated for allozymes and mtDNA in each population (Table 5). The numbers of introgressed (or alien) alleles penetrating $N$. cornutus and $N$. chrysocephalus were tabulated for allozymes and mtDNA, and their proportions were tested by $G$ tests. If introgression were random, the number of alien alleles in each species would be proportional to the frequencies of parental alleles at that locality.

Allozymes. - The absolute numbers of alien alleles, roughly indicating the numbers of backcrosses in each direction, are approximately equal towards $N$. cornutus and $N$. chrysocephalus (regardless of the drainage or relative abundance of parental types) at four of the seven localities $(2,4,5$, and 7; Table 5, Fig. 3). At the remaining three localities, increased numbers of alleles are introgressed toward $N$. chrysocephalus (the common parent) relative to $N$. cornutus. Therefore, the proportion of backcross alleles tends to be greater in the rare parent irrespective of drainage of origin (pooled across eastern localities, $G=5.30,0.01<$ 


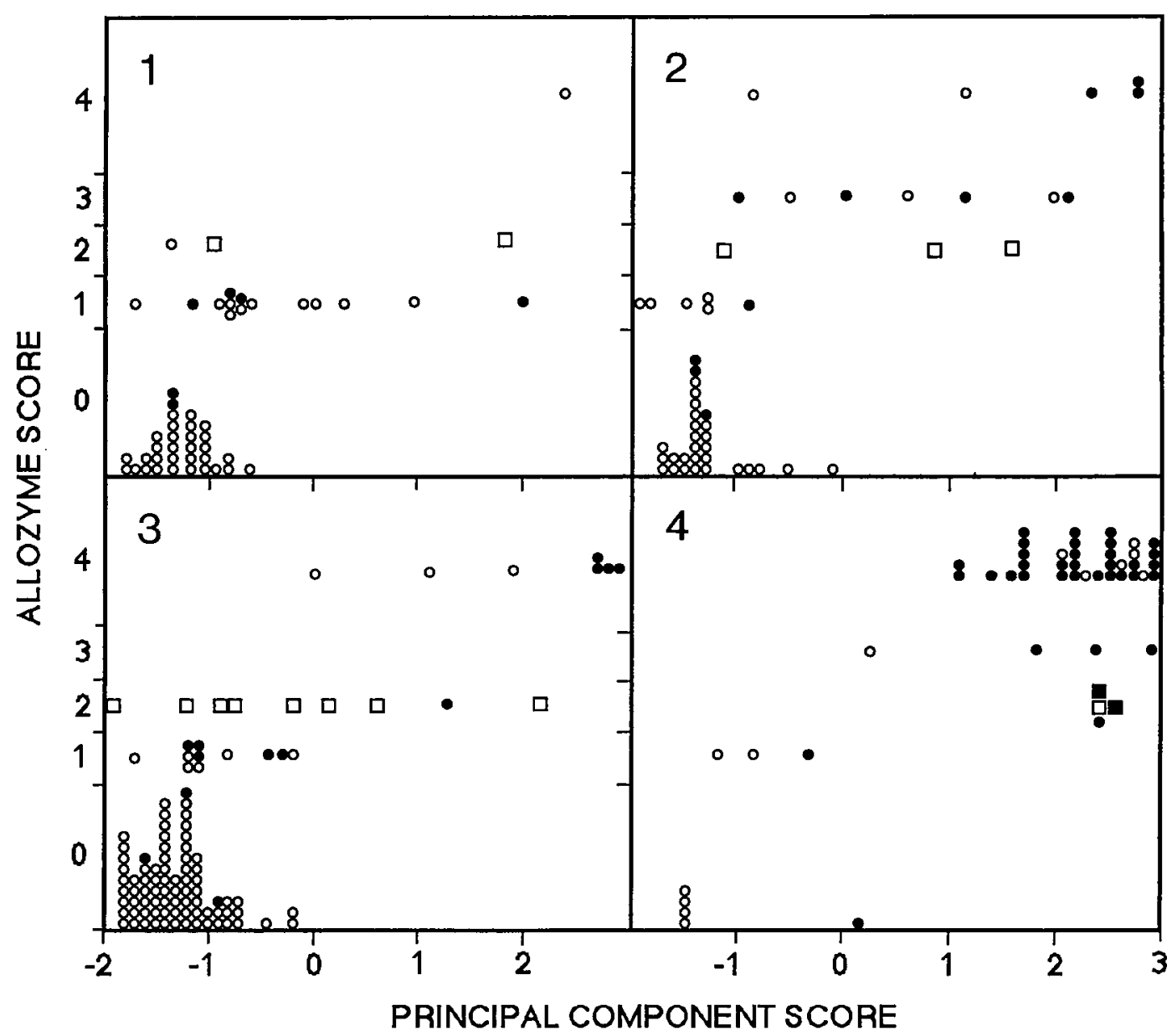

FIG. 3. Multicharacter representation of individuals from the eastern (1-4) and western (5-7) river drainages. For each locality, the morphological character index ( $x$-axis), is the principal-component score based on four pigment and scale-size characters $(N$. chrysocephalus-like to the left and $N$. cornutus-like to the right); allozymic character-index scores (y-axes) were calculated by tabulating the number of $N$. cornutus alleles in each individual ( $N$. cornutus typically has higher scores than $N$. chrysocephalus). $\mathrm{F}_{1}$ hybrids are represented by squares, and all other individuals are represented by circles. Solid symbols indicate $N$. cornutus mtDNA haplotypes, and open symbols indicate $N$. cornutus mtDNA haplotypes. (The numbers of individuals in the scatterplots differ from the totals in the tables in some instances, because individuals for which we lacked circumferential scale counts are not included.)

$P<0.025$; pooled across western localities, $G=3.68,0.05<P<0.10$ ). Since both types of backcrosses are predominant at several localities (4 and 5 for $N$. cornutus; $1,2,3,6$, and 7 for $N$. chrysocephalus), this implies a tendency for nonrandom reproduction of backcross types, favoring more frequent matings with the rare parent than would be expected due to chance. These results are consistent with the Hubbs (1955) hypothesis: rare parental types will participate in heterospecific crosses more frequently because of the lower frequency of homospecific encounters. In this situation, the rare parental type is eventually eliminated, relative to the backcross individuals, in the absence of immigration of new parental types into the population (e.g., locality 1 ).

Morphology. - The pattern of morphological introgression varies considerably from locality to locality, regardless of the drainage of origin (Fig. 3). All of the eastern localities have some individuals with discordant allozyme and morphological phenotypes (found in the upper left and lower right quadrants of Fig. 3), especially at locality 2 . These individuals were probably 


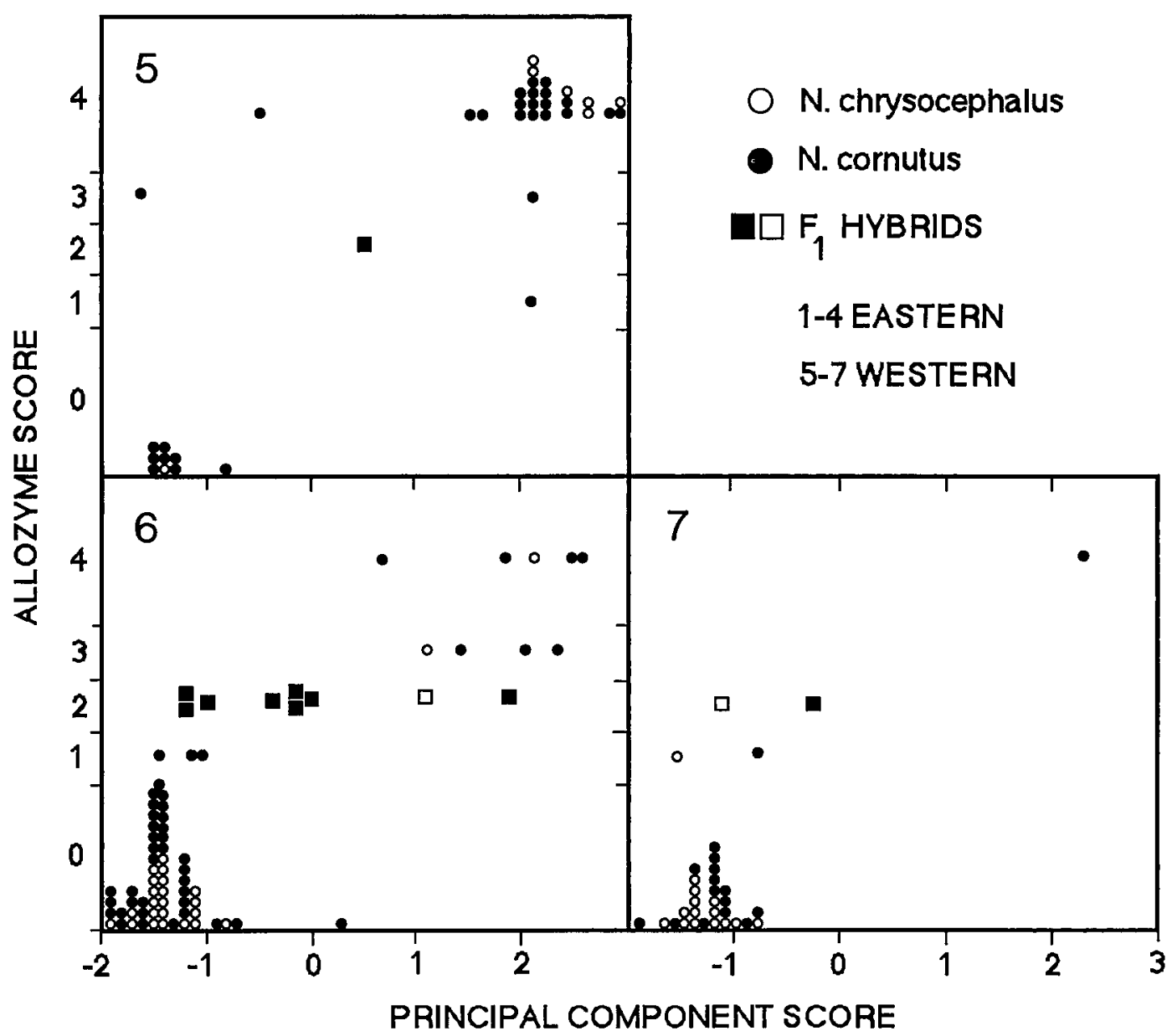

Fig. 3. Extended.

produced by reverse backcrossing or mating of $F_{1}$ hybrids (probably the former, given the rarity of $F_{1}$ 's). The western localities also exhibit variation in the pattern of morphological introgression. Localities 6 and 7 have backcrosses scattered along the diagonal between the parental types (Fig. 3), while locality 5 has several individuals in the upper left and lower right quadrants. Comparison of the morphological data also implicates introgressive elimination of the rare species, with localities 6 and 7 possibly representing early and late stages, respectively, of an introgression event.

$m t D N A$. - Unlike the introgression of nuclear alleles, introgression of mtDNA haplotypes appears to be different in eastern and western river drainages, although the pattern varies from locality to locality. At western drainage localities (5-7), mtDNA shows introgressive penetrance from $N$. cornutus to $N$. chrysocephalus $(G=13.22, P<0.001$, pooled across all three populations), independent of the relative abundance of parental types (rare vs. common, $G=0.46$, pooled across all three populations). The level of mtDNA introgression is considerably lower in eastern than in western river drainages and is predominantly from $N$. chrysocephalus into $N$. cornutus. However, like the allozyme data, mtDNA shows directional introgression towards the rare species, which is $N$. cornutus in three of the four eastern populations $(G=9.07,0.001<P<0.005$, pooled across all four populations).

\section{Discussion}

The comparison of data from mitochondrial DNA, allozymes, and morphology reveals variability in the causes and degree of 
TABLE 5. Extent of introgression of allozyme (Pgm-A + Pep-S) and mtDNA alleles toward $N$. cornutus (CO) and $N$. chrysocephalus $(\mathrm{CH})$ in each of seven populations and pooled across the eastern (populations 1-4) and western (populations 5-7) draining rivers. The symbols $N$, \#, and $\%$ give the total number of alleles, the number of alien alleles, and the percentage of alien alleles introgressing toward $N$. cornutus and $N$. chrysocephalus. The rows labelled Rare and Common present the data pooled by relative frequency of occurrence in eastern and western river drainages.

\begin{tabular}{|c|c|c|c|c|c|}
\hline \multirow[b]{2}{*}{ Locality } & \multirow[b]{2}{*}{$\mathrm{CO} / \mathrm{CH}$} & \multicolumn{2}{|c|}{ Allozymes } & \multicolumn{2}{|c|}{ mtDNA } \\
\hline & & $\# / N$ & $\%$ & $\# / N$ & $\%$ \\
\hline \multicolumn{6}{|c|}{ Eastern drainages: } \\
\hline \multirow[t]{2}{*}{1} & $\mathrm{CO}$ & $0 / 4$ & 0 & $1 / 1$ & 100 \\
\hline & $\mathrm{CH}$ & $16 / 188$ & 9 & $6 / 47$ & 12 \\
\hline \multirow[t]{2}{*}{2} & $\mathrm{CO}$ & $8 / 56$ & 14 & $6 / 14$ & 43 \\
\hline & $\mathrm{CH}$ & $9 / 164$ & 6 & $4 / 41$ & 10 \\
\hline \multirow[t]{2}{*}{3} & $\mathrm{CO}$ & $2 / 36$ & 6 & $3 / 9$ & 33 \\
\hline & $\mathrm{CH}$ & $11 / 364$ & 3 & $9 / 91$ & 10 \\
\hline \multirow[t]{2}{*}{4} & $\mathrm{CO}$ & $4 / 156$ & 3 & $7 / 39$ & 18 \\
\hline & $\mathrm{CH}$ & $3 / 32$ & 9 & $2 / 8$ & 25 \\
\hline \multicolumn{6}{|c|}{ Western drainages: } \\
\hline \multirow[t]{2}{*}{5} & $\mathrm{CO}$ & $4 / 156$ & 3 & $8 / 39$ & 20 \\
\hline & $\mathrm{CH}$ & $3 / 52$ & 6 & $11 / 13$ & 85 \\
\hline \multirow[t]{2}{*}{6} & $\mathrm{CO}$ & $4 / 36$ & 11 & $2 / 9$ & 22 \\
\hline & $\mathrm{CH}$ & $9 / 236$ & 4 & $37 / 59$ & 58 \\
\hline \multirow[t]{2}{*}{7} & $\mathrm{CO}$ & $0 / 4$ & 0 & $0 / 1$ & 0 \\
\hline & $\mathrm{CH}$ & $2 / 120$ & 2 & $14 / 30$ & 47 \\
\hline \multicolumn{6}{|l|}{ Pooled: } \\
\hline \multirow[t]{2}{*}{ East $(1-4)$} & $\mathrm{CO}$ & $14 / 252$ & 6 & $17 / 63$ & 27 \\
\hline & $\mathrm{CH}$ & $39 / 748$ & 5 & $21 / 187$ & 11 \\
\hline Rare & & $13 / 128$ & 10 & $12 / 32$ & 38 \\
\hline Common & & $40 / 872$ & 5 & $26 / 218$ & 12 \\
\hline \multirow[t]{2}{*}{ West (5-7) } & $\mathrm{CO}$ & $8 / 196$ & 4 & $10 / 49$ & 20 \\
\hline & $\mathrm{CH}$ & $14 / 408$ & 3 & $62 / 102$ & 61 \\
\hline Rare & & $7 / 92$ & 8 & $13 / 25$ & 57 \\
\hline Common & & $15 / 512$ & 3 & $59 / 128$ & 46 \\
\hline
\end{tabular}

restriction of gene flow between Notropis cornutus and $N$. chrysocephalus and differences in the amount and direction of introgression as revealed by these three sets of characters. Estimation of the extent of introgression for allozymes, morphology, and mtDNA (eastern river drainages only) reveals frequency-dependence but no significant differences in the direction of introgression between $N$. cornutus and $N$. chrysocephalus. The rare species, whichever it is, tends to exhibit a higher proportion of introgressed alleles than the more common one (see also Dowling and Moore [1984]). This bias might be explained by the difficulty rare individuals would have finding mates of their own species; they are there- fore more likely to hybridize (Hubbs, 1955; Avise and Saunders, 1984). Heterospecific mating behavior (as described above) in the rare form, coupled with environmental fluctuations, could lead local populations through a three-stage progression: 1) distinct parental populations at the same locality, with low levels of hybridization, 2) shifts in habitat affect the relative abundance of parental types, and increased gene flow occurs between parental populations, with the rarer population containing proportionally more backcross hybrids, and 3 ) near or complete absence of one species, with the majority of backcross hybrids grading into the more common parent. This process may be reversed by shifts in habitat structure favoring the rare parent and immigration of individuals of the rare species into the area.

Analysis of the introgression of mtDNA haplotypes suggests that there are asymmetrical differences in the extent of reproductive isolation in different drainages. In the western rivers (Grand and Kalamazoo, localities 5-7 [the Lake Michigan drainages]), the majority of the hybrids $\left(F_{1}\right.$ and backcross) exhibit $N$. cornutus mtDNA haplotypes, and introgression is strongly asymmetrical, with significantly more discordant haplotypes penetrating $N$. chrysocephalus than $N$. cornutus $(60.8 \%$ vs. $20.4 \%)$. The high frequency of $N$. cornutus mtDNA haplotypes in $F_{1}$ and backcross hybrids and the strong directionality of introgression, as exhibited by backcrosses, is not frequencydependent. It could be due to the reduced fitness of progeny resulting from crosses between $N$. cornutus males and $N$. chrysocephalus females and from backcrosses with $N$. cornutus or due to highly asymmetrical assortative mating of the parental species, $F_{1}$, and backcross hybrids.

In the eastern rivers (Huron and Raisin, localities 1-4 [the Lake Erie drainage]), the majority of $F_{1}$ and backcross hybrids exhibit $N$. chrysocephalus mtDNA haplotypes, although $N$. cornutus mtDNA is more common than expected in the backcross hybrids from some localities (Table 4), probably due to the rarity of this species at these localities. The extent of $N$. chrysocephalus mtDNA introgression into $N$. cornutus is not significantly different from that in the 
Lake Michigan drainages (26.7\% vs. $20.4 \%$ ), but flow of $N$. cornutus mtDNA into $N$. chrysocephalus is significantly lower in eastern than in western drainages $(11.2 \%$ vs. $60.8 \%$ ). The significantly higher occurrence of $F_{1}$ 's from matings between male $N$. cornutus and female $N$. chrysocephalus suggests that either selection or assortative mating is acting to reduce the number of $F_{1}$ hybrids. Frequency-dependence of allozyme and mtDNA introgression in the eastern drainages suggests that the distribution of backcrosses at eastern localities is also affected by either assortative mating or differential selection.

The mating behaviors of $N$. cornutus and $N$. chrysocephalus have been well documented (Reighard, 1910; Hankinson, 1932; Raney, 1940; Gilbert, 1964). Males defend breeding territories over the gravel nests of other minnow species (typically Nocomis and Semotilus) or over small depressions that they scrape into gravel beds. Females mass downstream from nesting sites and then rush over the nest to spawn with the dominant male, releasing small numbers of their eggs (less than 50) at each mating. Breeding coloration of males may differ between species, with Notropis cornutus males exhibiting bright red on their sides and intense black pigmentation over the rest of the body, while $N$. chrysocephalus males are more golden-brown with less red and very little black pigmentation (T. E. Dowling and G. R. Smith, unpubl.). Despite these pigment differences, no behavioral differences are known to exist between these species. These species have been reported to spawn simultaneously over the same gravel beds (Hankinson, 1932), and all possible mating combinations have been observed in natural populations (T. M. Berra, pers. comm.). These observations provide no evidence for assortative mating based on mate choice at the nest.

Smith et al. (1981) documented different habitat preferences in the Raisin River, where $N$. chrysocephalus is restricted to less turbid, faster-flowing water. $N$. cornutus is a generalist, occupying most habitats, and is one of the most common species in the Raisin River drainage. In Ohio, the distributional pattern is reversed, with $N$. chrysocephalus being widely distributed and $N$. cornutus restricted to cooler, less turbid streams and rivers (Trautman, 1981). While these differences may affect distributional patterns, abundance, and amount of spawning overlap, it is doubtful that they would result in effective reproductive isolation.

The mechanism most likely to be responsible for assortative mating, if such exists, involves differences in their optimal spawning temperatures and ranges (Gilbert, 1964). $N$. cornutus is more northern in its distribution and may spawn at lower temperatures than $N$. chrysocephalus. If so, the extent of hybridization could be variable over time and geography. In years when water temperature rises more rapidly in the spring and at localities less buffered against fluctuations in water temperature, spawning periods are more likely to overlap, resulting in increased hybridization. Such processes might have caused the variability found in these data (Table 4), where tests of mtDNA distribution in backcross hybrids provide evidence for random mating from two localities ( 2 and 5 ) and selection or assortative mating at the remaining localities.

Local habitat and fluctuations in temperature play an important role in determining the distribution and relative abundance of these species and, hence, influence the direction and amount of introgression between them. However, the pattern of mtDNA introgression in western river drainages appears to be consistent among localities and different from eastern river drainages. Two possible geographical explanations for the existence of differences in patterns of mtDNA introgression are 1) local effects due to differences in assortative mating, survivorship, or stochastic processes in eastern and western drainages and 2) genetic differences between drainages due to derivation of founder populations from different glacial refugia. While the four rivers in this survey are geographically very close (Fig. 1), differences in climate between eastern and western drainages could produce different selection backgrounds in different populations. Lake Michigan has a pronounced effect on cold air masses arriving from the northwest, as demonstrated by the western Michigan fruit belt.

The second hypothesis, derivation of eastern and western populations from ge- 
netically distinct founder stocks from different glacial refugia, combines genetic and historical factors. $N$. cornutus, being more tolerant of colder temperatures, probably arrived soon after the glaciers retreated. $N$. chrysocephalus, being less tolerant of cold temperatures, probably arrived much later, possibly after the closure of the Grand River connection between the eastern and western Great Lakes (Bailey and Smith, 1981). Present-day $N$. cornutus in the eastern and western river drainages may represent a genetic admixture of stocks derived from the Chicago and Maumee glacial refugia (through the Chicago and Maumee outlets, Fig. 1), while $N$. chrysocephalus in the eastern drainages may be derived only from the Maumee refugium, and individuals in the western drainages may be derived only from the Chicago refugium. If the above scenario is correct, differences in the pattern of mtDNA introgression, reflecting differences in reproductive isolation, between the two forms in eastern and western drainages could be the result of different responses to hybridization among genetically distinct stocks. This hypothesis is being tested by further analysis of other geographically distant populations from the zone of sympatry.

Variation in the level of reproductive isolation is well known from several other studies of hybridizing taxa (Nevo and BarEl, 1976; Gartside et al., 1979; Gartside, 1980; Shaw, 1981; Rising, 1983; Howard, 1986), and selection against $F_{1}$ and backcross hybrids is also well documented (Woodruff, 1979; Shaw, 1981; Harrison, 1983; Littlejohn and Watson, 1983; Kocher and Sage, 1986). N. cornutus and N. chrysocephalus, in addition to exhibiting these phenomena, show that $F_{1}$ and backcross hybrids may be the result of reciprocal matings (i.e., have different species as the maternal parent) at different localities, based on analysis of mtDNA.

Previous studies of allozymic variation in $N$. cornutus have demonstrated high withinspecies gene flow (Dowling and Moore, 1984, 1986). For local differences in reproduction and survival to maintain the observed patterns in the face of such strong gene flow, these differences must be significantly intense and may play an important role in the restriction of gene flow between species. If, however, the observed patterns are produced by genetic differences between different founder populations, local differences in reproduction and survival are less important, and one may ask how much genetic change is necessary for the production of such patterns. Since most of the mtDNA haplotypes (based on approximately 50 fragments surveyed for $A v a \mathrm{I}$, Hind III, and $M b o$ I) within each species are found in both eastern and western river drainages $(>80 \%$ for $N$. cornutus and $>99 \%$ for $N$. chrysocephalus), and since estimates of sequence divergence between populations tend to be an order of magnitude lower than those for between-species comparisons, the extent of divergence between populations seems limited, suggesting that the amount of genetic change necessary for the production of the observed differences in reproductive isolation is small.

\section{ACKNOWLEDGMENTS}

We thank S. Baldauf, K. L. Dowling, D. Foran, M. C. Hall, and W. R. Hoeh for assistance in collection of specimens; W. R. Hoeh for valuable technical assistance; $M$. C. Hall, W. R. Hoeh, W. S. Moore, and C. C. Moritz for valuable discussion and critical review of this work. This work was supported in part by NSF grants BSR-8516812 (to T.E.D. and G.R.S.) and BSR-8517830 and BSR-8516645 (to W.M.B.).

\section{Literature Cited}

AvISE, J. C. 1986. Mitochondrial DNA and the evolutionary genetics of higher animals. Phil. Trans. Roy. Soc. Lond. B 312:325-342.

Avise, J. C., J. ARnold, R. M. Ball, E. Bermingham, T. LAMB, J. E. Neigel, C. A. Reeb, AND N. C. SAUNDERS. 1987. Intraspecific phylogeography: The mitochondrial DNA bridge between population genetics and systematics. Ann. Rev. Ecol. Syst. 18:489-522.

Avise, J. C., E. Bermingham, L. G. Kessler, AND N. C. SAUNDERS. 1984. Characterization of mitochondrial DNA variability in a hybrid swarm between subspecies of bluegill sunfish (Lepomis macrochirus). Evolution 38:931-941.

Avise, J. C., AND R. A. Lansman. 1983. Polymorphism of mitochondrial DNA in populations of higher animals, pp. 109-145. In M. Nei and R. K. Koehn (eds.), Evolution of Genes and Proteins. Sinauer, Sunderland, MA.

Avise, J. C., AND N. C. SAunders. 1984. Hybridization and introgression among species of sunfish (genus Lepomis): Analysis by mitochondrial DNA and allozyme markers. Genetics 108:237-255. 
BaIley, R. M., AND G. R. Smith. 1981. Origin and geography of the fish fauna of the Laurentian Great Lakes Basin. Can. J. Fish. Aquat. Sci. 38:15391561.

Barton, N. H., and G. H. HewitT. 1981. Hybrid zones and speciation, pp. 109-145. In W. R. Atchley and D. S. Woodruff (eds.), Essays on Evolution and Speciation in Honor of M. J. D. White. Cambridge Univ. Press, Cambridge, U.K.

- 1985. Analysis of hybrid zones. Ann. Rev. Ecol. Syst. 16:113-148.

Barton, N. H., AND J.S. Jones. 1983. Mitochondrial DNA: New clues about evolution. Nature 306:3 17318.

Brown, W. M. 1980. Polymorphism in mitochondrial DNA of humans as revealed by restriction endonuclease analysis. Proc. Nat. Acad. Sci. USA 77:3605-3609.

Brown, W. M., M. George, Jr., AND A. C. Wilson. 1979. Rapid evolution of animal mitochondrial DNA. Proc. Nat. Acad. Sci. USA 76:1967-1971.

Brown, W. M., E. M. Prager, A. Wang, and A. C. WILSON. 1982. Mitochondrial DNA sequences of primates: Tempo and mode of evolution. J. Molec. Evol. 18:225-239.

Bush, G. L., AND D. J. Howard. 1985. Allopatric and non-allopatric speciation; Assumptions and evidence, pp. 411-438. In S. Karlin and E. Nevo (eds.), Evolutionary Processes and Theory. Academic Press, London, U.K.

COCKERHAM, C. C. 1969. Variance of gene frequencies. Evolution 23:72-84.

-1973. Analyses of gene frequencies. Genetics 74:679-700.

Densmore, L. D., J. W. Wright, AND W. M. BRown. 1985. Length variation and heteroplasmy are frequent in mitochondrial DNA from parthenogenetic and bisexual lizards (genus Cnemidophorus). Genetics 110:698-707.

Dowling, T. E., AND W. S. MoORE. 1984. Level of reproductive isolation between two cyprinid fishes, Notropis cornutus and $N$. chrysocephalus. Copeia 1984:617-628.

- 1985a. Evidence for selection against hybrids in the family Cyprinidae (genus Notropis). Evolution 39:152-158.

- 1985b. Genetic variation and divergence of the sibling pair of cyprinid fishes, Notropis cornutus and $N$. chrysocephalus. Biochem. Syst. Ecol. 13: $471-476$.

- 1986. Absence of population subdivision in the common shiner, Notropis cornutus (family Cyprinidae). Env. Biol. Fishes 15:151-155.

Ferris, S. D., R. D. Sage, C. Huang, J. T. Nielsen, U. RitTe, AND A. C. Wilson. 1983. Flow of mitochondrial DNA across a species boundary. Proc. Nat. Acad. Sci. USA 80:2290-2294.

GARTSIDE, D. F. 1980. Analysis of a hybrid zone between chorus frogs of the Pseudacris nigrita complex in the southeastern United States. Copeia 1980: 56-66.

GARTSIDE, D. F., M. J. LitTLEJOHN, AND G. F. WATSON. 1979. Structures and dynamics of a narrow hybrid zone between Geocrinia laevis and $G$. victoriana (Anura: Leptodactylidae) in southeastern Australia. Heredity 43:165-177.
GilberT, C. R. 1961. Hybridization versus introgression: An inquiry into the relationship of two cyprinid fishes. Copeia 1961:181-192.

- 1964. The American cyprinid fishes of the subgenus Luxilus (genus Notropis). Bull. Florida St. Mus. Biol. Sci. 8:95-194.

HANkINSON, T. L. 1932. Observations on the breeding behavior and habitats of fishes in southern Michigan. Pap. Mich. Acad. Sci. Arts Let. 14:411425.

HARRISON, R. G. 1983. Barriers to gene exchange between closely related cricket species. I. Laboratory hybridization studies. Evolution 37:245-251.

HARRISON, R. G., D. M. RAND, AND W. C. WHEELER. 1987. Mitochondrial DNA variation across a narrow hybrid zone. Molec. Biol. Evol. 4:144-158.

Heth, G., AND E. Nevo. 1981. Origin and evolution of ethological isolation in subterranean mole rats. Evolution 35:259-274.

HowARD, D. J. 1986. A zone of overlap between two ground cricket species. Evolution 40:34-43.

HuBBs, C. L. 1955. Hybridization between fish species in nature. Syst. Zool. 4:1-20.

KANESHIRO, K. V. 1976. Ethological isolation and phylogeny in the planitibia subgroup of Hawaiian Drosophila. Evolution 30:740-745.

—. 1980. Sexual isolation, speciation and the direction of evolution. Evolution 34:437-444.

KoCHER, T. D., AND R. D. SAGE. 1986. Further genetic analyses of a hybrid zone between leopard frogs (Rana pipiens complex) in central Texas. Evolution 40:21-33.

LAMB, T., AND J. C. AvISE. 1987. Morphological variability in genetically defined categories of anuran hybrids. Evolution 41:157-165.

LitTlejohn, M. J., AND G. F. Watson. 1983. The Litoria ewingi complex (Anura: Hylidae) in southeastern Australia. VII. Mating call structure and genetic incompatability across a narrow hybrid zone between $L$. ewingi and $L$. paraewingi. Aust. J. Zool. 31:193-204.

MOORE, W. S. 1977. An evaluation of narrow hybrid zones in vertebrates. Quart. Rev. Biol. 52:263-277.

- 1979. A single locus mass-action model of assortative mating, with comments on the process of speciation. Heredity 42:173-186.

- 1987. Random mating in the Northern Flicker hybrid zone: Implications for the evolution of bright and contrasting plumage patterns in birds. Evolution 41:539-546.

MoORE, W. S., AND D. B. BuchanaN. 1985. Stability of the Northern Flicker hybrid zone in historical times: Implications for adaptive speciation theory. Evolution 39:135-151.

Moritz, C., T. E. Dowling, AND W. M. BRown. 1987. Evolution of animal mitochondrial DNA: Relevance for population biology and systematics. Ann. Rev. Ecol. Syst. 18:269-292.

Muller, H. J. 1942. Isolating mechanisms, evolution and temperature. Biol. Symp. 6:71-125.

NefF, N. A., AND G. R. SmITH. 1978. Multivariate analysis of hybrid fishes. Syst. Zool. 28:176-196.

Nevo, E., AND H. BAR-El. 1976. Hybridization and speciation in fossorial mole rats. Evolution 30:831840.

PAterson, H. E. H. 1978. More evidence against 
speciation by reinforcement. S. Afr. J. Sci. 74:369371.

Powell, J. R. 1983. Interspecific cytoplasmic gene flow in the absence of nuclear gene flow: Evidence from Drosophila. Proc. Nat. Acad. Sci. USA 80: 492-495.

RANEY, E. C. 1940. The breeding behavior of the common shiner, Notropis cornutus. Zoologica 25: 1-14.

REIGHARD, J. E. 1910. Methods of studying the habits and breeding behavior of fishes with an account of the breeding habits of the horned dace. Bull. U.S. Bur. Fish. 28:1113-1136.

Rising, J. D. 1983. The progress of oriole hybridization in Kansas. Auk 100:885-897.

Ross, M. R., AND T. M. CAVENDER. 1981. Morphological analyses of four experimental intergeneric cyprinid hybrid crosses. Copeia 1981:377-387.

SHAw, D. D. 1981. Chromosomal hybrid zones in orthopteroid insects, pp. 146-170. In W. R. Atchley and D. S. Woodruff (eds.), Essays on Evolution and Speciation in Honor of M. J. D. White. Cambridge Univ. Press, Cambridge, U.K.

Smith, G. R., J. N. Taylor, and T. W. Grimshaw. 1981. Ecological survey of fishes in the Raisin River drainage, Michigan. Pap. Mich. Acad. Arts Sci. Let. 13:275-305.

SPOLSKY, C., AND T. Uzzell. 1984. Natural interspecies transfer of mitochondrial DNA in amphibians. Proc. Nat. Acad. Sci. USA 81:5802-5805.

SzymuRA, J. M., C. Spolsky, AND T. Uzzell. 1985. Concordant mitochondrial and nuclear genes in a hybrid zone between two frog species (genus Bombina). Experentia 41:1469-1470.

TAKahata, N., AND M. Slatkin. 1984. Mitochondrial gene flow. Proc. Nat. Acad. Sci. USA 81:17641767.

Tegelstrom, H. 1987. Transfer of mitochondrial DNA from the northern red-backed vole (Cleithrionomys rutilus) to the bank vole (C. glareolus). J. Molec. Evol. 24:218-227.

Trautman, M. B. 1981. The Fishes of Ohio. Ohio State Univ. Press, Columbus.

VAWTER, L., AND W. M. BROWN. 1986. Nuclear and mitochondrial DNA comparisons reveal extreme rate variation in the molecular clock. Science 234: 194-196.

Wirson, A. C., R. L. Cann, S. M. Carr, M. George, JR., U. B. GyLlenstein, K. Helm-Bychowski, R. G. Higuchi, S. R. Palumbi, E. M. Prager, R. D. SAGE, AND M. StonekING. 1985. Mitochondrial DNA and two perspectives on evolutionary genetics. Biol. J. Linn. Soc. 26:375-400.

WoODRUFF, D.S. 1979. Postmating reproductive isolation in Pseudophryne and the evolutionary significance of hybrid zones. Science 203:561-563.

Wright, J. M., C. SPOLSKY, AND W. M. BROWN. 1983. The origin of the parthenogenetic lizard Cnemidophorus laredoensis inferred from mitochondrial DNA analysis. Herpetologica 39:410-416.

ZAR, J. 1974. Biostatistical Analysis. Prentice-Hall, Englewood Cliffs, NJ.

Corresponding Editor: C. F. Aquadro 